\title{
Analisis Portofolio Optimum Saham Syariah Menggunakan Mean Semivarian
}

\author{
Fantika Vera Entrisnasari \\ Program Studi Matematika Fakultas Sains dan Teknologi, UIN Sunan Kalijaga, Jl. Marsda Adisucipto \\ No. 1 Yogyakarta, Indonesia \\ Korespondensi; Email: fantikavera@gmail.com
}

\begin{abstract}
Abstrak
Saham adalah salah satu sekuritas yang sering dipilih untuk melakukan investasi. Dalam investasi saham, seorang investor harus membuat portofolio optimal agar memperoleh hasil yang memuaskan (return tinggi atau risiko rendah). Salah satu metode untuk membentuk portofolio optimal adalah metode mean-varians yang diperkenalkan Markowitz, tapi metode ini mempunyai asumsi yang sering tidak terpenuhi dalam kenyataannya. Sehingga Markowitz memperkenalkan metode mean-semivarians dari pendekatan risiko menurun. Dalam prakteknya, metode mean-varians lebih sering digunakan daripada metode mean-semivarians karena perhitungan meansemivarians yang lebih sulit. Populasi pada penelitian ini adalah seluruh saham yang termasuk pada saham Jakarta Islamic Index (JI) periode Juni 2013 - Mei 2015. Indeks Sharpe portofolio metode mean-semivarians adalah 0,020098155 .
\end{abstract}

Kata Kunci: Portofolio O ptimal; Saham Syariah; Mean-varians; Mean-semivarians

\begin{abstract}
Stocks are one of the securities that are often chosen for investment. In stock investing, an investor has to make optimal portfolio in order to obtain a satisfactory result (return high or low risk). One method for forming the optimal portfolio is mean-variance method introduced Markowitz, but this method has the assumptions that are often not met in reality. So Markowitz mean-semivarians introduced a method of decreasing risk approach. In practice, the mean-variance method is used instead of the mean-semivarians method for calculation of the meansemivarians more difficult. The population in this study are all the shares including the shares of Jakarta Islamic Index (JI) in the period June 2013 - in May 2015. Sharpe index portfolio mean-semivarians method is 0.020098155.
\end{abstract}

Keywords: O ptimum Portfolio; Islamic stocks; Mean-varians; Mean-semivarians

\section{Pendahuluan}

Modern ini, masyarakat dituntut untuk mengoptimalkan pendapatannya untuk memenuhi kebutuhan hidup. Pendapatan tidak lagi dialokasikan hanya untuk memenuhi kebutuhan konsumsi, tapi juga investasi. Investasi adalah komitmen sejumlah dana atau sumber daya lainnya yang dilakukan saat ini, dengan tujuan untuk memperoleh keuntungan di masa yang akan datang (Tandelilin, 2012:3). Keputusan investasi yang dilakukan tiap-tiap investor akan berbeda bergantung pada tujuan investasi dan keberanian mereka dalam menanggung risiko atas investasi yang dilakukan. Lima tahapan yang dilalui dalam mengambil keputusan investasi yaitu, menentukan kebijakan investasi, memilih strategi portofolio, memilih aset yang akan diinvestasikan, dan melakukan pengukuran serta evaluasi kinerja portofolio (Tandelilin, 2012:12).

Saham merupakan salah satu sekuritas yang sering dipilih untuk melakukan investasi. Saham dapat diartikan klaim atas pendapatan yang diperoleh dari aktivitas pengelolaan aset bisnis atau perusahaan (Manurung dan Adler, 2009:5). Dari hasil jual-beli saham, investor mendapatkan keuntungan berupa capital gain/loss. Investor juga bisa memperoleh keuntungan berupa dividen dengan menanamkan dana pada suatu sekuritas dalam rentang waktu yang relatif lama dibandingkan investasi untuk jual-beli 
saham. Capital gain/loss dan dividen biasanya disebut return atau tingkat pengembalian atas suatu investasi.

Investor yang berinvestasi dalam bentuk portofolio perlu melakukan analisis terhadap peluang return dan risiko yang akan dihadapi. Return dan risiko berhubungan searah, dengan kata lain saham memiliki karakteristik high risk-high return. Artinya saham merupakan surat berharga yang memberikan peluang keuntungan yang tinggi namun juga berpotensi risiko yang tinggi. Investasi dapat dilakukan, salah satunya dengan membentuk portofolio optimum. Portofolio optimum merupakan portofolio yang dipilih seorang investor dari sekian banyak alternatif yang ada pada kumpulan portofolio yang efisien. Pemilihan portofolio tersebut disesuaikan dengan preferensi investor yang bersangkutan terhadap return maupun risiko yang melekat pada portofolio yang dipilihnya.

Model penentuan portofolio optimum yang menekankan pada hubungan return dan risiko investasinya adalah model Markowitz. Markowitz memperkenalkan model mean-varians pada tahun 1952. Pada model ini, Markowitz menggunakan mean untuk merepresentasikan nilai return dan varians untuk ukuran risiko yang didapat. Model portofolio markowitz memanfaatkan hubungan rata-rata return dengan variansi return untuk memperoleh variansi (risiko) yang paling kecil. Dengan menggunakan portofolio ini investor dapat meminimalkan risiko dengan tingkat harapan keuntungan (expected return) tertentu.

Model mean-varians Markowitz (1959) telah dikritik oleh para peneliti karena asumsi pada model tersebut. Model mean-varians mempunyai dua asumsi yang harus dipenuhi yaitu distribusi data return aset berdistribusi normal dan investor mempunyai fungsi utilitas kuadrat. Model ini tidak konsisten dengan maksimalisasi prinsip utilitas yang diharapkan jika dua kondisi tersebut tidak terjadi. Namun, dua kondisi ini tidak terjadi dalam praktek. Banyak peneliti telah menunjukkan bahwa distribusi return aset asimetris dan menunjukkan skewness. Fungsi utilitas kuadrat juga sangat tidak mungkin karena menyiratkan investor sama-sama menolak return positif maupun negatif (Saiful dkk, 2011).

Kelemahan dari model mean-varians membuat para peneliti menawarkan model-model lain dalam membuat portofolio optimal, salah satunya adalah model mean-semivarians. Markowitz (1959) menyatakan bahwa analisis berdasarkan semivarians menghasilkan portofolio yang lebih optimal daripada mean-varians yang menggunakan varians sebagai ukuran risiko, karena semivarians adalah ukuran yang lebih masuk akal sebagai ukuran risiko. Tapi meski demikian model mean-varians lebih sering digunakan daripada model mean-semivarians. Hal tersebut dikarenakan model mean-varians menggunakan matriks varians-kovarians yang bersifat simetrik dan endogen sehingga perhitungan lebih mudah, daripada model mean-semivarians yang menggunakan matriks semivarians-semikovarians yang berifat asimetrik dan endogen, yang artinya perubahan pada bobot berpengaruh pada periode saat portofolio underperform terhadap Benchmark, sehingga untuk menghitungnya harus menggunakan algoritma numerik yang jarang digunakan praktisi atau akademisi. Untuk mengatasi masalah ini, Estrada (2008) menyarankan untuk menggunakan pendekatan heuristik untuk mengubah matriks semivarianssemikovarians menjadi simetrik dan eksogen, sehingga dapat dihitung seperti cara pada model meanvarians.

JII (Jakarta Islamic Index) menawarkan 30 saham yang halal yang dapat dijadikan pilihan investasi, terutama dalam membentuk portofolio. Saham JII dapat menjadi alternatif pilihan bagi investor untuk melakukan investasi pada saham berbasis syariah dan menjalankan syariah Islam untuk melakukan investasi di bursa efek. JII menjadi jawaban atas keinginan investor yang ingin berinvestasi sesuai syariah. Dengan kata lain, JII menjadi pemandu bagi investor yang ingin menanamkan dananya secara syariah tanpa takut tercampur dengan dana ribawi. Maka dari itu, penulis menjadikan JII sebagai studi kasus untuk membuat portofolio optimal dengan menggunakan model mean-varians dan meansemivarians yang selanjutnya akan dibandingkan model yang lebih baik untuk digunakan dari keduanya.

\section{Landasan Teori}

\section{Pasar Modal Syariah}

Pasar modal adalah pasar yang mempertemukan pihak-pihak yang memerlukan dana jangka panjang dan mereka yang menyediakan dana tersebut yang biasa disebut dengan bursa efek. Sedangkan yang 
dimaksud dengan pasar modal syariah menurut Firdaus et al. (2005) adalah pasar modal yang menetapkan prinsip-prinsip syariah, antara lain yaitu:

1. Larangan terhadap setiap transaksi yang mengandung unsur ketidakjelasan.

2. Instrumen atau efek yang diperjualbelikan harus memenuhi kriteria halal.

Investasi keuangan menurut syariah dapat dikaitkan dengan perdagangan atau kegiatan usaha baik berbentuk produk, aset ataupun jasa. Syariah memberikan dasaran bahwasanya berinvestasi harus terkait langsung dengan suatu aset atau kegiatan usaha yang menghasilkan manfaat. Berkaitan dengan pasar modal maka investasi yang dapat dilakukan adalah membeli saham perusahaan baik non publik maupun publik. Investasi di saham perusahaan publik dapat dilakukan melalui pembelian saham pada pasar perdana maupun pasar sekunder. Investasi yang dapat dilakukan di pasar modal, yaitu:

1. Pembelian Saham

Saham yang dapat dibeli adalah saham-saham yang sesuai dengan kriteria Dewan Syariah Nasional (DSN). Adapun kaidah-kaidah syariah yang dapat dipenuhi dalam instrumen saham antara lain, yaitu:

a. Akad yang digunakan adalah musyarakah atau mudharabah jika ditawarkan secara terbatas.

b. Revenue atau hasil yang ditawarkan berupa bagi hasil bukan rate atau kupon.

c. Emiten adalah perusahaan halal dan islami menurut kriteria DSN.

d. Semua akad pada pasar perdana berbasis transaksi riil (underlying asset jelas) bukan untuk mebayar hutang.

e. Tidak boleh spekulasi, gharar dan maysir.

2. Pembelian Obligasi Pembiayaan Usaha Syariah

Obligasi Syariah adalah surat berharga jangka panjang berdasarkan prinsip syariah yang dikeluarkan oleh emiten kepada investor dengan kewajiban memberikan bagi hasil serta membayar kembali dana obligasi pada saat jatuh tempo. Obligasi syariah adalah suatu kontrak perjanjian tertulis jangka panjang untuk membayar kembali pada waktu tertentu beserta seluruh manfaat secara periodik menurut akad. Instrumen obligasi syariah berdasarkan fatwa DSN No. 32/DSN-MUI/IX/2002 dapat diterbitkan dengan menggunakan prinsip mudharabah tergantung dengan emiten.

\section{Saham JII}

Suryomurti (2011) menjelaskan tentang JII dalam bukunya. Jakarta Islamic Index atau biasa disebut JII adalah salah satu indeks saham yang ada di Indonesia yang menghitung index harga ratarata saham untuk jenis saham-saham yang memenuhi kriteria syariah. Saham-saham yang masuk dalam JII adalah saham-saham dari perusahaan yang dianggap sudah menjalankan bisnis secara syariah. Saham yang masuk JII sudah melewati satu penyaringan ketat. Seleksinya dilihat dari dua segi. Pertama dilihat dari industrinya, yaitu bukan satu perusahaan yang menghasilkan produk-produk yang bertentangan dengan syariat islam. Dengan alasan itu, saham yang memproduksi minuman beralkohol, berkaitan dengan perjudian, kegiatan usahanya berbau maksiat, dan lembaga keuangan konvensional tidak dapat masuk dalam saham JII. Kedua, dilihat dari sisi keuangannya, yaitu dengan melihat rasio hutang atas aset, rasio piutang atas aset, rasio interest income atas pendapatan perusahaan. Penilaian saham ini dilakukan setiap enam bulan sekali. Dari 30 jenis saham yang masuk JII tersebut tercatat hanya ada 16 saham yang terus-menerus masuk dalam indeks syariah tersebut.

Pembentukan JII tidak lepas dari kerja sama antara Pasar Modal Indonesia (dalam hal ini PT Bursa Efek Jakarta) dengan PT Danareksa Investment Management (PT DIM). JII telah dikembangkan sejak tanggal 3 Juli 2000. Pembentukan instrumen syariah ini untuk mendukung pembentukan Pasar Modal Syariah yang kemudian diluncurkan di Jakarta pada tanggal 14 Maret 2003. Mekanisme Pasar Modal Syariah meniru pola serupa di Malaysia yang digabungkan dengan bursa konvensional seperti Bursa Efek Jakarta dan Bursa Efek Surabaya. Setiap periodenya, saham yang masuk JII berjumlah 30 (tiga puluh) saham yang memenuhi kriteria syariah.

Penentuan kriteria dalam pemilihan saham dalam JII melibatkan Dewan Pengawas Syariah PT DIM. Saham-saham yang akan masuk ke JII harus melalui filter syariah terlebih dahulu. Berdasarkan arahan Dewan Pengawas Syariah PT DIM, ada 4 syarat yang harus dipenuhi agar saham-saham tersebut dapat masuk ke JII (Suyomurti, 2011):

1. Emiten tidak menjalankan usaha perjudian dan permainan yang tergolong judi atau perdagangan yang dilarang 
2. Bukan lembaga keuangan konvensional yang menerapkan sistem riba, termasuk perbankan dan asuransi konvensional

3. Usaha yang dilakukan bukan memproduksi, mendistribusikan, dan memperdagangkan makanan/minuman yang haram

4. Tidak menjalankan usaha memproduksi, mendistribusikan, dan menyediakan barang/jasa yang merusak moral dan bersifat mudharat

Selain filter syariah, saham yang masuk ke dalam JII harus melalui beberapa proses penyaringan (filter) terhadap saham yang listing (Suyomurti, 2011), yaitu:

1. Memilih kumpulan saham dengan jenis usaha utama yang tidak bertentangan dengan prinsip syariah dan sudah tercatat lebih dari 3 bulan, kecuali termasuk dalam 10 kapitalisasi besar.

2. Memilih saham berdasarkan laporan keuangan tahunan atau tengah tahun berakhir yang memiliki rasio kewajiban terhadap aktiva maksimal sebesar $90 \%$.

3. Memilih 60 saham dari susunan saham di atas berdasarkan urutan rata-rata kapitalisasi pasar terbesar selama 1 (satu) tahun terakhir.

4. Memilih 30 saham dengan urutan berdasarkan tingkat likuiditas rata-rata nilai perdagangan reguler selama 1 (satu) tahun terakhir.

Pengkajian ulang akan dilakukan 6 (enam) bulan sekali dengan penentuan komponen indeks pada awal bulan Januari dan Juli setiap tahunnya. Sedangkan perubahan pada jenis usaha utama emiten akan dimonitor secara terus menerus berdasarkan data publik yang tersedia. Perusahaan yang mengubah lini bisnisnya menjadi tidak konsisten dengan prinsip syariah akan dikeluarkan dari indeks. Sedangkan saham emiten yang dikeluarkan akan diganti oleh saham emiten lain. Semua prosedur tersebut bertujuan untuk mengeliminasi saham spekulatif yang cukup likuid. Sebagian saham-saham spekulatif memiliki tingkat likuiditas rata-rata nilai perdagangan reguler yang tinggi dan tingkat kapitalisasi pasar yang rendah.

\section{Portofolio Efisien dan Portofolio Optimal}

Menurut Bodie et al. (2006) dalam pembentukan portofolio investor selalu ingin memaksimalkan return yang diharapkan dengan tingkat risiko tertentu yang bersedia ditanggungnya atau mencari portofolio yang menawarkan risiko terendah dengan dengan tingkat return tertentu. Karakteristik portofolio seperti ini disebut juga dengan portofolio efisien.

Dalam pembentukkan portofolio yang efisien harus berpedoman pada asumsi tentang perilaku investor dalam membuat keputusan investasi yang akan diambil. Salah satu asumsi yang paling penting adalah pada umumnya semua investor tidak menyukai risiko (risk averter). Investor seperti ini jika dihadapkan pada beberapa alternatif investasi yang menawarkan return yang sama, dengan risiko yang berbeda akan cenderung memilih investasi dengan risiko yang lebih rendah.

Membentuk portofolio yang efisien perlu diperhatikan koefisien tingkat keuntungan dari masingmasing aset yang membentuk portofolio. Koefisien korelasi dari suatu portofolio mencerminkan keeratan hubungan antara tingkat keuntungan dari aset-aset yang membentuk portofolio.

Portofolio yang efisien akan mempunyai koefisien korelasi dari aset-aset yang mendekati negatif satu. Jika koefisien korelasi positif satu, maka portofolio tidak akan bermanfaat karena tidak akan mengurangi risiko, dan apabila koefisien korelasi positif sempurna, maka harga kedua aset tersebut sama-sama naik atau sama-sama turun, sehingga portofolio yang terbentuk tidak mempengaruhi.

Portofolio optimal merupakan portofolio yang dipilih seorang investor dari sekian banyak alternatif yang ada pada kumpulan portofolio yang efisien. Pemilihan portofolio tersebut disesuaikan dengan preferensi investor yang bersangkutan terhadap return maupun risiko yang melekat pada portofolio yang dipilihnya.

\section{Kinerja Portofolio}

Perkembangan konsep pengukuran kinerja portofolio terjadi pada akhir tahun 1960-an yang dipelopori oleh Wiliam Sharpe, Trenor, dan Michael Jensen. Konsep ini berdasarkan teori Capital Market. Ketiga ukuran ini dikenal dengan istilah composite (risk-adjusted) measure of portofolio performance karena mengkombinasikan antara return dan risk dalam suatu perhitungan (Jogiyanto, 2003). Ketiga ukuran kinerja tersebut adalah sebagai berikut: 


\section{Indeks Sharpe}

Salah satu metode yang digunakan untuk membandingkan kinerja portofolio dengan menggunakan konsep dari Garis Pasar Modal/ Capital Market Line (CML) atau lebih dikenal dengan istilah Reward to Variability Rasio (RVAR). Dimana Sharpe menyatakan kinerja portofolio dihitung merupakan hasil bersih dari portofolio dengan tingkat bunga bebas risiko per unit. Indeks Sharpe dihitung dengan formula sebagai berikut (Manurung, 2000):

$$
\text { i1 Sha }=\frac{\mu-R_{f}}{\sigma}
$$

Dengan $R_{f}$ adalah risk free rate atau tingkat bebas risiko, $\mu$ sebagai mean, dan $\sigma^{2}$ sebagai variansi dari return $\left(\mu=E\left(r_{t}\right)\right.$ dan $\left.\sigma^{2}=V \quad\left(r_{t}\right)\right)$.

2. Indeks Treynor

Treynor sebagai salah satu indeks yang digunakan untuk mengukur kinerja portofolio, Treynor sering dikenal dengan istilah Reward to Valatility Ratio (RVOR). Oleh karenanya Indeks Treynor menyatakan kinerja portofolio dihitung merupakan hasil bersih dari portofolio dengan tingkat suku bunga bebas risiko per unit risiko pasar portofolio tersebut. Indeks kinerja Treynor dihitung dengan formula berikut (Manurung, 2000):

$$
\text { i1 } \quad T \quad=\frac{\mu-R_{f}}{\beta_{p}}
$$

Dengan $\mu=E\left(r_{t}\right)$ sebagai mean, dan $\beta_{p}$ sebagai beta portofolio pada periode tertentu, dengan $R_{f}$ adalah risk free rate atau tingkat bebas risiko.

Dalam menghitung Indeks Treynor ini maka asumsi yang harus diperhatikan bahwa hasilnya memberikan evaluasi pada satu periode, karena tingkat pengembalian portofolio dan risiko membutuhkan periode yang panjang. Bila periode yang dipergunakan cukup pendek maka risiko yang dihitung dengan beta memberikan hasil yang tidak wajar atau tidak representatif. Disamping itu asumsi normalitas dari tingkat pengembalian perlu juga diperhatikan.

3. Indeks Jensen

Sebagai salah satu ukuran kinerja portofolio, Jensen sangat memperhatikan CAPM dalam mengukur kinerja portofolio, sehingga sering disebut dengan Jesen ALPHA (differential return measure). Jensen ALPHA merupakan sebuah ukuran absolut yang mengestimasikan tingkat pengembalian konstan selama periode investasi yang memperoleh tingkat Jensen ALPHA pengembalian diatas (dibawah) dari buy-hold strategy dengan risiko sistematik yang sama. Adapun formula Jensen ALPHA sebagai berikut (Manurung, 2000):

$$
\alpha_{p}=R_{p}-\left[R_{f}+\beta_{p}\left(R_{m}-R_{f}\right)\right]
$$

Semakin tinggi $\alpha_{p}$ yang positif maka kinerja portofolionya semakin baik.

Jensen ALPHA dapat dihitung dengan cara lain yaitu dengan menyederhanakan persamaan diatas menjadi persamaan dibawah ini:

$$
R_{p}-R_{f}=\alpha_{p}+\beta_{p}\left(R_{m}-R_{f}\right)
$$

Dengan $R_{f}$ adalah risk free rate, $\beta_{p}$ adalah beta portofolio pada periode tertentu, $R_{m}$ adalah return market.

Persamaan diatas memperlihatkan adalah risiko portofolio dipengaruhi oleh risiko market. Nilai $\alpha$ dan $\beta$ pada persamaan diatas diestimasikan sesuai dengan model yang dikenal dengan regresi. Oleh karenanya data asli runtun waktu dari portofolio, tingkat pengembalian pasar dan tingkat bunga bebas risiko harus tersedia.

Nilai $\alpha$ yang tertinggi dan siginifikan merupakan portofolio yang terbaik dari portofolio yang ada. 


\section{Metode Mean Semivarian}

Markowitz memperkenalkan permasalahan optimasi portofolio pada tahun 1952. Diketahui bahwa permasalahan pokok optimasi portofolio adalah tingkat kepuasan (utilitas) investor yang bergantung pada expected return dan risiko portofolionya, yang biasa dihitung dengan varians dari return saham. Dalam perkembangannya, Markowitz (1959) tertarik dengan ukuran risiko lain, yaitu semivarians dari return saham. Dalam bukunya, Markowitz (1991: 194) menyatakan bahwa analisis yang didasarkan pada $S$ (semivarians) menghasilkan portofolio yang lebih baik daripada yang didasarkan pada $V$ (varians). Pada edisi revisi, Markowitz (1991: 374) mengklaim bahwa semivarians adalah ukuran yang lebih masuk akal untuk menghitung risiko. Markowitz menyatakan hal itu karena seorang investor lebih mengkhawatirkan portofolio yang underperform daripada overperform, sehingga semideviasi lebih tepat digunakan sebagai ukuran risiko daripada varians.

Pada metode mean-varians, risiko dihitung dengan menggunakan standart deviasi dari return saham. Mean-varians juga memiliki asumsi bahwa data return berdistribusi normal dan investor mempunyai fungsi utilitas kuadrat. Sedangkan metode mean-semivarians menghitung risiko dengan semideviasi dengan benchmark B. Selain itu, Cumova (2007) menyatakan bahwa mean-semivarians tidak memiliki asumsi distribusi apapun. Hal ini membuat mean-semivarians terlihat menjadi lebih ungggul daripada mean-varians.

Pada kenyataannya, mean-varians lebih sering digunakan daripada mean-semivarians. Hal ini dikarenakan sifat semivarians-semikovarians yang digunakan untuk menghitung bobot saham pada metode mean-semivarians bersifat asimetrik dan endogen, yaitu jika periode saat portofolio underperform terhadap benchmark, maka akan mempengaruhi perubahan bobot saham yang dibentuk. Selain itu, untuk menghitung semivarians harus menggunakan algoritma numerik yang jarang digunakan oleh akademisi atau praktisi. Berbeda dengan mean-varians yang memiliki varians-kovarians yang bersifat simetrik dan eksogen. Untuk menyelesaikan permasalahan di atas, Estrada (2008) menawarkan solusi untuk mengubah matriks semivarians-semikovarians menjadi simetrik dan eksogen dengan menggunakan pendekatan heuristik. Sehingga dapat dihitung seperti cara yang digunakan mean-varians.

\section{Optimasi Portofolio Mean-semivarians dengan Pendekatan Heuristik}

Diberikan $R$ sebagai realisasi return dan $c$ sama dengan $E(R)$ atau $c$ adalah konstanta pilihan portofolio, maka $S$ (semivarians) dituliskan sebagai berikut: (Markowitz, 1990)

$$
S=E\left(M \quad(0, R-c)^{2}\right)
$$

Jadi, jika diberikan ukuran penyebaran semua pengamatan yang berada di bawah nilai rata-rata atau target dari kumpulan data. Semivarians adalah rata-rata semideviasi kuadrat dari nilai-nilai yang kurang dari rata-rata.

Semivarians mirip dengan varians, namun itu hanya mempertimbangkan pengamatan bawah ratarata. Sebuah alat yang berguna dalam portofolio atau analisis aset, semivarians memberikan ukuran risiko downside. Sementara standart deviasi dan varians menyediakan ukuran volatilitas, semivarians hanya melihat fluktuasi negatif aset. Dengan menetralkan semua nilai di atas rata-rata, atau investor target return, semivarians memperkirakan kerugian rata-rata portofolio. Untuk investor risk averter, pemecahan untuk alokasi portofolio optimal dengan meminimalkan semivarians akan membatasi kemungkinan kerugian besar.

Seperti yang dibahas sebelumnya bahwa ukuran risiko yang digunakan mean-semivarians adalah semivarians, Markowitz (1959) menyarankan sebuah pendekatan untuk estimasi semivarians dari portofolio, sebagai berikut:

$$
S_{i l}=\frac{1}{T} \sum_{k=1}^{K}\left[w_{i} R_{i l}\right]^{2}=\frac{1}{T} \sum_{k=1}^{K}\left[R_{p}\right]^{2}
$$

Dengan $T$ adalah jumlah observasi dan $K$ adalah jumlah periode return portofolio berada di bawah target return. Dan estimasi semivarians dari portofolio antara aset $i$ dan $j$ dengan benchmark $B$ menurut Markowitz juga dapat ditulis sebagai berikut: 


$$
S_{i,}=\sum_{i=1}^{n} \sum_{j=1}^{n} w_{i} w_{j} S_{i}
$$

Dengan,

$$
S_{i_{1}}=\frac{1}{T} \sum_{k=1}^{K}\left[\left(R_{i l}-B\right) \cdot\left(R_{j l}-B\right)\right]
$$

Persamaan semivarians diusulkan oleh Markowitz di atas masih bersifat endogen, yaitu bobot berpengaruh pada periode saat portofolio underperform terhadap benchmark, yang juga akan berpengaruh pada perhitungan matriks semivarians-semikovarians.

Dibandingkan dengan semivarians, lebih rumit untuk menghitung semikovarians dari aset $i$ dan $j$. Hogan dan Waren (1974) juga pernah mendefinisikan semikovarians sebagai berikut:

$$
S_{i}^{H}=E\left\{\left(R_{i}-R_{f}\right) \cdot M \quad\left(R_{i}-R_{f}, 0\right)\right\}
$$

Dengan $i \neq j, \quad i=1,2, \ldots, \mathrm{n}, j=1,2, \ldots, \mathrm{n}$ dan $R_{f}$ adalah risk free rate yaitu return minimum yang diharapkan investor, sedangkan subskrip $H W$ adalah definisi yang diusulkan oleh Hogan dan Waren. Tapi definisi ini mempunyai 2 kekurangan, yaitu:

1. Return benchmark terbatas pada tingkat risk free rate dan tidak dapat diganti dengan benchmark yang lain.

2. $S_{i}{ }^{H} \neq S_{j}{ }^{H}$. Karakter ini akan membatasi baik secara formal (matriks semikovarians biasanya asimetris) dan intuitif (tidak jelasnya kontribusi asset $i$ dan $j$ terhadap risiko portofolio).

Estrada (2002, 2007) telah menemukan solusi yang lebih baik untuk mendefinisikan semivarians dan semikovarians, setelah melihat kekurangan pada peneliti sebelumnya. Estrada mengusulkan definisi semivarians dari return aset $i$ dengan benchmark $B$ yang, sebagai berikut:

$$
\begin{aligned}
S_{i} & =E\left\{\left[M \quad\left(R_{i}-B, 0\right)\right]^{2}\right\} \\
& =\frac{1}{T} \sum_{t=1}^{T}\left[M \quad\left(R_{i t}-B, 0\right)\right]^{2}
\end{aligned}
$$

dengan $i=1,2, \ldots, \mathrm{n}, t=1,2, \ldots, T$ dan $B$ adalah return benchmark yang dipilih investor. Akar kuadrat dari persamaan (9) adalah semideviasi yang merupakan risiko dari aset $\mathrm{i}$ dengan benchmark $B$, ini adalah sebuah ukuran yang sangat sering digunakan pada ukuran risiko downside.

Estrada $(2002,2007)$ juga mendefinisikan semikovarians dari asset $i$ dan $j$ dengan benchmark $B$, sebagai berikut:

$$
\begin{aligned}
S_{i} & =E\left\{\left[M \quad\left(R_{i}-B, 0\right) \cdot M \quad\left(R_{j}-B, 0\right)\right]\right\} \\
& =\frac{1}{T} \sum_{t=1}^{T}\left[M \quad\left(R_{i}-B, 0\right) \cdot M \quad\left(R_{j}-B, 0\right)\right]
\end{aligned}
$$

Untuk definisi di atas benchmark $B$ dapat diganti sesuai dengan yang diinginkan investor, menghasilkan semikovarians yang simetris $\left(S_{i}=S_{j}\right)$ dan eksogen.

Misalkan ada $n$ saham dengan rata-rata return saham $r_{i}$, bobot $w$ dan semikovarians return saham $S_{i}$ membentuk portofolio, serta $B$ adalah return benchmark yang dipilih investor. Maka bentuk fungsi risiko dari portofolio mean-semivarians dapat ditulis sebagai berikut:

$$
\sum_{i=1}^{n} \sum_{j=1}^{n} w_{i} w_{j} S_{i}
$$

Dengan $i \neq j, i=1,2, \ldots, \mathrm{n}, j=1,2, \ldots, \mathrm{n}$, dan $S_{i} \quad$ seperti yang telah terdefinisikan pada (10). Fungsi risiko di atas dapat dibentuk model optimasi portofolio mean-semivarians sebagai berikut: Minimize $\sum_{i=1}^{n} \sum_{j=1}^{n} w_{i} w_{j} S_{i}$

Dengan kendala sebagai berikut: $\sum_{i=1}^{n} w_{i} r_{i}=R_{p} ; \sum_{i=1}^{n} w_{i}=1$ 


$$
0 \leq w_{i} \leq 1, i=1, \ldots, n
$$

$R_{p}$ adalah return dari portofolio mean-semivarians.

Pendekatan heuristik pada optimasi portofolio mean-semivarians ini didasarkan pada estimasi semivarians portofolio dengan menggunakan persamaan (11) dengan $S_{i}$ yang terdefinisi pada persamaan (10) menghasilkan matriks semivarians-semikovarians yang simetris dan eksogen. Jika semivarians-semikovarians telah simetris dan eksogen, maka tujuan mean-varians dan mean-semivarians menjadi sama, yaitu meminimumkan risiko berdasarkan tingkat ekspektasi return tertentu.

\section{Pembobotan Portofolio Metode Mean-semivarians}

Dijelaskan sebelumnya bahwa dengan pendekatan heuristik dapat mengubah matriks semivarianssemikovarians yang bersifat asimetris dan endogen menjadi simetris dan eksogen. Sehingga tujuan mean-semivarians menjadi sama dengan mean-varians, yaitu meminimumkan risiko berdasarkan tingkat ekspektasi return tertentu.

Pembobotan portofolio dilakukan dengan bobot $w=\left(w_{1}, \ldots, w_{N}\right)^{\top}$ dan tujuan untuk meminimumkan risiko berdasarkan mean return dari portofolio yang terbentuk atau meminimumkan semivariansi dari portofolio. Sehingga dari fungsi optimasi (12) dapat diubah menjadi bentuk berikut:

Minimize $w^{T} \underline{\Delta}_{m}$

Dengan kendala:

$$
\begin{aligned}
& w^{T} \mu=\mu_{p} \\
& w^{T} 1=1
\end{aligned}
$$

dengan 1 adalah matriks kolom dengan element 1 dan $\mu_{p}$ adalah expected return portofolio. Selanjutnya akan dicari pembobotan portofolio optimal dengan cara meminimumkan persamaan return portofolio dari $n$ aset dengan batasan $w^{T} \mu=\mu_{p}$ dan $w^{T} 1=1$ Digunakan fungsi Lagrange dengan dua pengali yaitu $\lambda$ dan $\beta$ untuk menyelesaikan masalah optimisasi tersebut, diperoleh fungsi Lagrange sebagai berikut:

$$
L=w^{T} \underline{\Delta}_{m}{ }^{w}+\lambda\left(\mu_{p}-w^{T} \mu\right)+\beta\left(1-w^{T} \underline{1}\right)=0
$$

Mencari turunan parsial dari $\mathrm{L}$ terhadap $w^{T}$ :

$$
\begin{aligned}
\frac{\partial}{\partial w^{T}}=\underline{\Delta}_{m} \quad w-\lambda-\beta \underline{1} & =0 \\
\underline{\Delta}_{m}{ }^{w} & =\lambda-\beta \underline{1} \\
w & =\underline{\Delta}_{m}{ }^{-1}(\lambda-\beta \underline{1})
\end{aligned}
$$

Lalu persamaan (15) dikalikan $\underline{1}^{T}$ :

$$
\begin{aligned}
\underline{1}^{T} w & =\underline{1}^{T} \underline{\Delta}_{m}{ }^{-1}(\lambda-\beta \underline{1}) \\
1 & =\underline{1}^{T} \underline{\Delta}_{m}{ }^{-1}(\lambda-\beta \underline{1}) \\
1 & =\underline{1}^{T} \underline{\Delta}_{m}{ }^{-1} \lambda+\underline{1}^{T} \underline{\Delta}_{m}{ }^{-1} \beta \underline{1} \\
\underline{1}^{T} \underline{\Delta}_{m}{ }^{-1} \beta \underline{1} & =1-\underline{1}^{T} \underline{\Delta}_{m}{ }^{-1} \lambda \\
\beta & =\frac{1-\underline{1}^{T} \underline{\Delta}_{m}{ }^{-1} \lambda}{\underline{1}^{T} \underline{\Delta}_{m}{ }^{-1} \underline{1}}
\end{aligned}
$$

Mensubtitusikan persamaan (4.25) (16) pada persamaan (15):

$$
w=\underline{\Delta}_{m}-1\left(\lambda+\frac{1-\underline{1}^{T} \underline{\Delta}_{m}^{-1} \lambda}{\underline{1}^{T} \underline{\Delta}_{m}^{-1} \underline{1}} \underline{1}\right)
$$




$$
\begin{aligned}
& w=\underline{\Delta}_{m}-1\left(\lambda+\frac{1-\underline{1}^{T} \underline{\Delta}_{m}{ }^{-1} \lambda \underline{1}}{\underline{1}^{T} \underline{\Delta}_{m}{ }^{-1} \underline{1}}\right) \\
& w=\underline{\Delta}_{m}{ }^{-1} \lambda+\frac{\underline{\Delta}_{m}{ }^{-1} \underline{1}}{\underline{1}^{T} \underline{\Delta}_{m}{ }^{-1} \underline{1}}-\underline{\Delta}_{m}-1\left(\frac{\underline{\underline{1}}^{T} \underline{\Delta}_{m}{ }^{-1} \lambda \underline{1}}{\underline{1}^{T} \underline{\Delta}_{m}{ }^{-1} \underline{1}}\right)
\end{aligned}
$$

Karena untuk portofolio efisien maka tidak ada batasan pada mean portofolio $(\mu=0)$, sehingga didapat formula pembobotan portofolio optimal mean-varians sebagai berikut:

$$
W=\frac{\underline{\Delta}_{m}{ }^{-1} \underline{1}}{\underline{1}^{T} \underline{\Delta}_{m}}
$$

\section{Hasil dan Pembahasan}

Empat saham yang mempunyai Indeks Sharpe tertinggi sekaligus terpilih sebagai sampel pembentukkan portofolio optimal adalah Astra Agro Lestari Tbk. (AALI), Kalbe Farma Tbk. (KLBF), United Tractors Tbk. (UNTR), dan Unilever Indonesia Tbk. (UNVR).

Pada metode mean-semivarians dengan pendekatan heuristic menggunakan matriks semivarianssemikovarians untuk menghitung proporsi masing-masing saham. Matriks semivarians-semikovarians dibentuk dari semivarians dan semikovarians saham-saham yang terpilih, sebagai berikut:

$$
\Delta_{m S v}=\left[\begin{array}{cccc}
S_{1 B}^{2} & S_{12 B} & S_{13 B} & S_{14 B} \\
S_{21 B} & S_{2 B}^{2} & S_{23 B} & S_{24 B} \\
S_{31 B} & S_{32 B} & S_{3 B}^{2} & S_{34 B} \\
S_{41 B} & S_{42 B} & S_{43 B} & S_{4 B}^{2}
\end{array}\right]
$$

dengan $1=\mathrm{AALI}, 2=\mathrm{KLBF}, 3=\mathrm{UNTR}, 4=\mathrm{UNVR}$ dan $B=$ return benchmark. Untuk menghitung semivarians menggunakan rumus sebagai berikut:

$$
S_{i i}=\frac{1}{T} \sum_{t=1}^{T}\left[M \quad\left(R_{i 1}-B, 0\right)\right]^{2}
$$

dan menghitung semikovarians dengan rumus sebagai berikut:

$$
S_{i} \quad=S_{j} \quad=\frac{1}{T} \sum_{t=1}^{T}\left[M \quad\left(R_{i}-B, 0\right) \cdot M \quad\left(R_{j}-B, 0\right)\right]
$$

Setelah dilakukan perhitungan dengan menggunakan Mirosoft Office Excel 2007 dan Matlab 6.1 didapatkan hasil semivarians-semikovarians sebagai berikut:

$$
\Delta_{m s v}=\left[\begin{array}{llll}
2,610773285 & 0,831152524 & 1,279794256 & 1,040339201 \\
0,831152524 & 1,827595075 & 1,102497159 & 1,033174495 \\
1,279794256 & 1,102497159 & 2,745591998 & 1,152840406 \\
1,040339201 & 1,033174495 & 1,152840406 & 1,861888982
\end{array}\right]
$$

Matrik semivarians-semikovarians di atas kemudian dihitung invers matriksnya dengan menggunakan Mirosoft Office Excel 2007 didapatkan matriks invers semivarians-semikovarians sebagai berikut:

$$
\Delta_{m S v}^{-1}=\left[\begin{array}{cccc}
0,54937116 & -0,052161054 & -0,159989307 & -0,178957365 \\
-0,052161054 & 0,875371019 & -0,183064807 & -0,343254255 \\
-0,159989307 & -0,183064807 & 0,583928698 & -0,170577066 \\
-0,178957365 & -0,343254255 & -0,170577066 & 0,933173811
\end{array}\right]
$$


Berikutnya, menghitung proporsi masing-masing saham dengan rumus pembobotan saham metode mean-semivarians yang sudah ditulis pada bab sebelumnya, yaitu sebagai berikut:

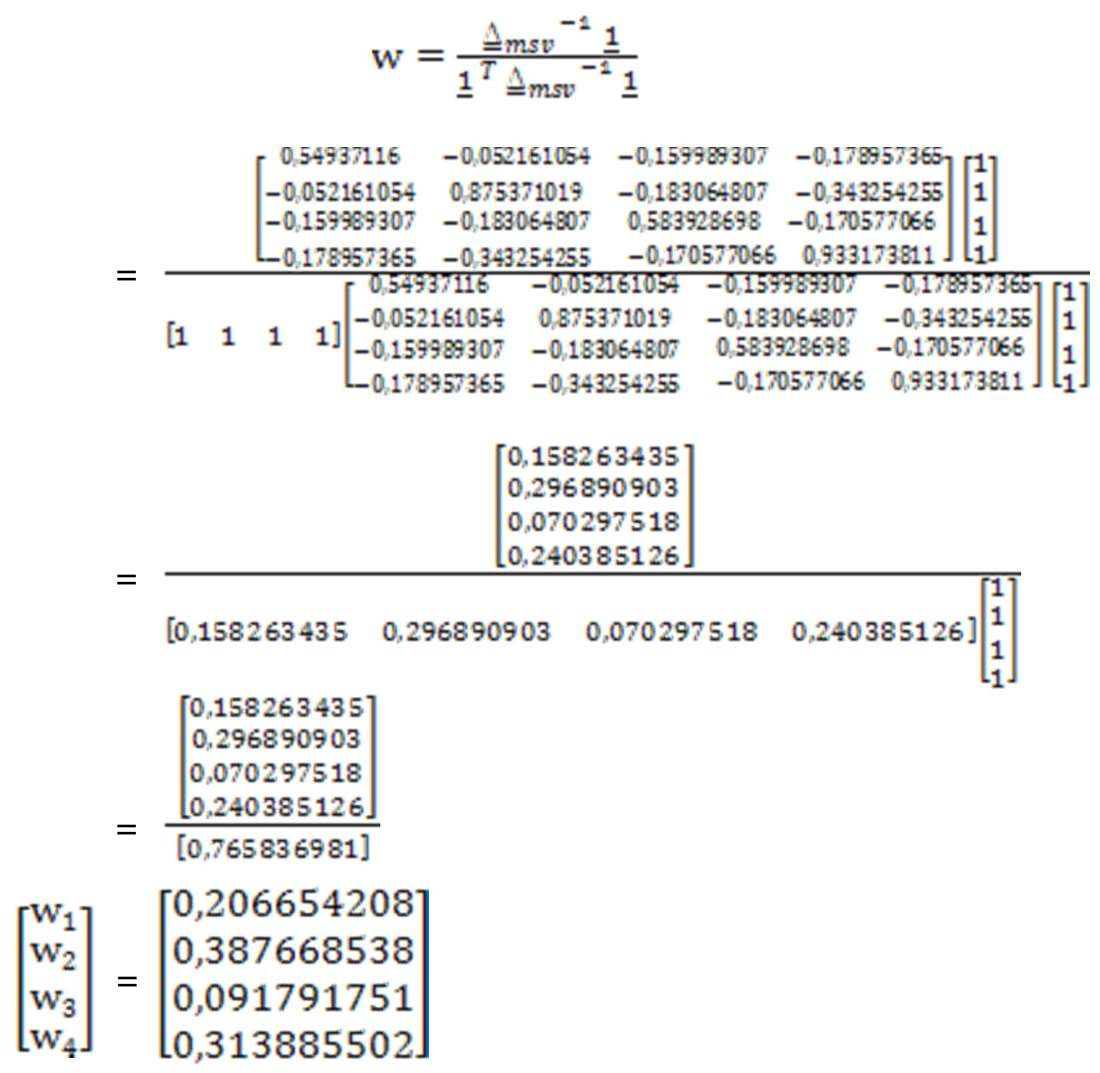

Sehingga didapat proporsi saham yang dihitung dengan metode mean-semivarians adalah sebagai berikut:

Tabel 1 Proporsi Saham Metode Mean-Semivarians.

\begin{tabular}{cllc}
\hline No & Kode & Nama Emiten & Proporsi \\
\hline 1 & AALI & Astra Agro Lestari Tbk. & $20,665 \%$ \\
2 & KLBF & Kalbe Farma Tbk. & $38,767 \%$ \\
3 & UNTR & United Tractors Tbk. & $9,179 \%$ \\
4 & UNVR & Unilever Indonesia Tbk. & $31,389 \%$ \\
\hline
\end{tabular}

Berdasarkan proporsi yang diperoleh dengan metode mean-semivarians maka didapatkan nilai return ekspektasi portofolio $E\left(R_{p}\right)$ sebagai berikut:

Tabel 2 Perhitungan Return Ekspektasi Portofolio Metode Mean-Semivarians.

\begin{tabular}{clccc}
\hline No & $\begin{array}{l}\text { Kode } \\
\text { Saham }\end{array}$ & $W i$ & $E(R i)$ & Wi.E(Ri) \\
\hline 1 & AALI & 0,206654 & 0,056519 & 0,01168 \\
2 & KLBF & 0,387669 & 0,040285 & 0,015617 \\
3 & UNTR & 0,091792 & 0,073538 & 0,00675 \\
4 & UNVR & 0,313886 & 0,064255 & 0,020169 \\
\hline \multicolumn{4}{c}{ Return Ekspektasi Portofolio } & 0,054216 \\
\hline
\end{tabular}


Dengan risiko portofolio sebagi berikut:

$$
\begin{aligned}
& \sigma_{v}{ }^{2}=[0,20660,38760,09170,3138]\left[\begin{array}{llll}
2,610773285 & 0,831152524 & 1,279794256 & 1,040339201 \\
0,831152524 & 1,827595075 & 1,102497159 & 1,033174495 \\
1,279794256 & 1,102497159 & 2,745591998 & 1,152840406 \\
1,040339201 & 1,033174495 & 1,152840406 & 1,861888982
\end{array}\right]\left[\begin{array}{l}
0,2066 \\
0,3876 \\
0,0917 \\
0,3138
\end{array}\right] \\
& =[1,3057609171,3057609171,3057609171,305760917]\left[\begin{array}{l}
0,2066 \\
0,3876 \\
0,0917 \\
0,3138
\end{array}\right] \\
& =1,305760916
\end{aligned}
$$

Risiko portofolio adalah akar kuadrat dari $\sigma_{p}{ }^{2}$, sehingga didapat risiko portofolio dengan metode meansemivarians adalah 1,142698961

Indeks Sharpe pada portofolio dengan metode mean-semivarians dihitung dengan tingkat suku bunga pada bulan Mei 2015 yang didapat dari www.bi.go.id adalah 7,5\%, maka risk free rate yang digunakan untuk menghitung Indeks Sharpe adalah 0,03125. Dengan demikian, didapatkan Indeks Sharpe pada portofolio dengan metode mean-semivarians adalah sebagai berikut:

$$
\text { indeks sharpe }=\frac{0,05421614-0,03125}{1,142698961}=0,020098155
$$

\section{Kesimpulan}

Pembentukkan portofolio saham dengan menggunakan metode mean-semivarians, yaitu: AALI 20,665\%, 38,767\%, UNTR 9,179\%, UNVR 31,389\%, dengan ekspektasi return portofolio 5,421 \% dan risiko portofolio 114,269\%. Dengan Indeks Sharpe portofolio metode mean-semivarians adalah 0,020098155.

\section{Referensi}

[1] Anton, Howard. Chris Rorres. 2004. Aljabar Linear Elementer. Edisi Kedelapan. Jilid 1. Jakarta : Erlangga.

[2] Bain, L. J., Engelhardt M. 1992. Introduction To Probability and Matheatical Statistics. California: Duxbury.

[3] Bodie, Zvi. Alex Kane dan Alan J. Marcus. 2006. Investasi. Jakarta: Salemba Empat.

[4] Cumova, D., Nawrocki D. 2007. A Symmetric LPM Model for Mean-Semivariance Optimization.

[5] Elton, E.J, dan Grubber. 1995. Modern Portfolio Theory and Invesment Analysis. Edisi Kelima. New York: John Wiley \& Sons Inc.

[6] Estrada, Javier. 2002. Mean-Semivariance Behavior: An Alternative Behavioral Model. IESE Bussiness School, Spain. Hal: 1-17.

[7] Estrada, Javier. 2003. Mean-Semivariance optimization: A Note. Journal of Finance. Hal: 9-14.

[8] Estrada, Javier. 2007. Mean-Semivariance Behavior: Downside Risk and Capital Asset Pricing. International Review of Economics and Finance 16 (No. 2). Hal: 169-185.

[9] Estrada, Javier. 2008. Mean-Semivariance optimization: A Heuristic Approach. Journal of Applied Finance. Hal: 57-72

[10] Fahmi, Irham. 2013. Pengantar Pasar Modal. Bandung : Alfabeta. Hal 54-67, 81, 219-228.

[11] Fahmi, Irham. 2014. Manajemen Keuangan Perusahaan dan Pasar Modal. Jakarta: Mitra Wacana Media.

[12] Firdaus, M. Sofiniyah Ghufron. Muhammad Aziz Hakim dan Mukhtar Alshodiq. 2005. Sistem Kerja Pasar Modal Syariah. Jakarta: Renaisan.

[13] Hafizah, Saiful. Weng Hoelan dan Zaidi Isa. 2011. Different Downside Risk Approaches in Portofolio Optimisation. Journal of Qualit Measurement and Analysis. JQMA 7 (1). Hal: 77-84.

[14] Hogan, William W. dan James M. Warren. 1974. Toward The Development Of An Equilibrium Capital-Market Model Based On Semivariance. Journal of Financial and Quantitative Analysis. Hal: 1-11.

[15] Husnan, Suad. 2005. Dasar-dasar Teori Portofolio \& Analisis Sekuritas. Edisi Keempat. Yogyakarta:UPP STIM YKPN.

[16] Jin, H. Markowitz, H. dan Xun Yu Zhou. 2006. A Note on Semivariance. Mathematical Finance. Hal: 53-61.

[17] Jogiyanto. 2003. Analisis Investasi dan Teori Portofolio. Yogyakarta: Gajah Mada Press.

[18] Jogiyanto. 2010. Teori Portofolio dan Analisis Investasi. Edisi Ketujuh. Yogyakarta: BPFE.

[19] Kotchlamazashvili, Zurab. 2014. Empirical Analysis of The EU Term Structure of interest Rates. Berlin: Logos Verlag. Hal: 25-27.

[20] Manurung, Adler Haymans. 2000. Mengukur Kinerja Portofolio. Majalah Usahawan. No 11 Nopember XXIX. Hal: $41-$ 46. 
[21] Manurung, Adler Haymans. 2006. Ke Mana Investasi? Kiat dan Panduan Investasi Keuangan Indonesia. Jakarta: Kompas. Hal : 153-155.

[22] Manurung, Jonni. dan Adler Haymans Manurung. 2009. Ekonomi Keuangan dan Kebijakan Moneter. Jakarta: Salemba Empat.

[23] Markowitz H. 1959. Portofolio Selection: efficient Diversification of Investments. Edisi Pertama. New York: John Wiley \& Sons.

[24] Markowitz H. 1991. Foundations of Portfolio Theory. Journal of Finance. Hal: 469-477.

[25] Markowitz H. Todd P. Xu G. Yamane Y. 1993. Computation of mean-semivariance efficient sets by the critical line algorithm. Annals ofr operations research. Hal: 307-317.

[26] Panggabean, A. B. 2008. Kalkulus. Yogyakarta: Graha Ilmu. Hal: 57-61.

[27] Rosadi, D. 2009. Diktat Kuliah Manajemen Resiko Kuantitatif. Program Studi Statistika. FMIPA Universitas Gadjah Mada.

[28] Samsul, Mohamad. 2007. Pasar Modal \& Manajemen Portofolio. Jakarta: Erlangga.

[29] Setyanto, Budi. 2006. Menyusun Portofolio Investasi Optimal Reksa Dana Batasa Syariah dengan Metode Markowitz. Jurnal Ekonomi Keuangan dan Bisnis. Vol. 2 No. 4. Hal: 39-58.

[30] Suryomurti, Wiku. 2011. Supercerdas Investasi Syariah. Jakarta: Qultum Media

[31] Tandelilin, E. 2001. Analisis Investasi dan Manajemen Portofolio. Edisi Pertama. Yogyakarta: BPFE.

[32] Vasant, Jiten. Laurent Irgolic. Kanshukan Rajaratnam. dan Ryan Kruger.2014. A Comparison of Mean-Variance and Mean-Semivariance Optimisation on The JSE. The Journal of Applied Business Research 30 (No:6). Hal: 1587-1596.

[33] Wahyuni, Septi. 2013. Perbandingan Optimisasi Portofoilo Metode Mean-Variane dengan Metode Mean-Semivariance. Tugas Akhir. Yogyakarta: Universitas Gadjah Mada.

[34] Wayan, I Degeng. 2007. Kalkulus Lanjut: Persamaan Differensial dan Aplikasinya. Yogyakarta : Graha IImu. Hal 1317.

[35] Zivot, Eric. Jiahui Wang. 2013. Modeling Financial Time Series with S-PLUS. New York: Springer Science+Business Media. Hal: 43-45. 